\title{
PARTICIPAÇÃO SOCIAL NAS POLÍTICAS PÚBLICAS FEDERAIS DO BRASIL: UMA ANÁLISE DOS FORMATOS E DESENHOS DOS ARRANJOS PARTICIPATIVOS VINCULADOS ÂS POLÍTICAS PÚBLICAS
}

\author{
Enid Rocha Andrade da Silva \\ Instituto de Pesquisa Econômica Aplicada, Brasil \\ enid.rocha@ipea.gov.br
}

\begin{abstract}
RESUMEN
Los últimos diez años en Brasil fueron pródigos en la creación de mecanismos de participación -consejos, conferencias, mesas redondas, defensores del pueblo, las audiencias públicas, talleres para la participaciónen la elaboración del Plan Plurianual y el establecimiento de estructuras administrativas en el cumplimiento de las demandas de los movimientos sociales. El artículo sostiene que los esfuerzos en materia de participación social tuvieron como objetivo dotar a la administración pública federal de una mayor capacidad institucional y de herramientas e instrumentos para mejorar la permeabilidad del ciclo de políticas públicas a las exigencias de la sociedad. La búsqueda de una nueva propuesta de reorganización del aparato del Estado que tuviera a la participación social como un elemento fundante de la acción del del gobierno federal resultó limitada para romper con el legado dejado por los proyectos políticos de los gobiernos anteriores. Sin embargo, el avance cuantitativo de la participación social en el período contribuyó a aumentar el control social haciendo al Estado más permeable al interés público, con una matriz participativo-democrática.
\end{abstract}

Palabras clave: Participación social, Políticas públicas, Estado, Sociedad, Brasil. 


\title{
SOCIAL PARTICIPATION IN FEDERAL PUBLIC POLICIES IN BRAZIL: AN ANALYSIS OF THE FORMS AND DESIGNS OF PARTICIPATORY ARRANGEMENTS RELATED TO PUBLIC POLICIES
}

\begin{abstract}
The last ten years in Brazil were lavish in creating participatory arrangements - councils, conferences, roundtables, ombudsmen, public hearings, and workshops for participation -, in the drafting of the Multi-Year Plan and the establishment of administrative structures in the meeting the of the demands of social movements. The article argues that the efforts on social participation aimed to provide the federal public administration with greater institutional capacity, as well as tools and instruments for enhancing the permeability of the public policy cycle to the demands of society. The search for a new reorganization proposal for the state apparatus, which embraced social participation as a fundamental element of the actions of the federal government, proved insufficient to break with the legacy left by the political projects of previous governments. However, the quantitative progress of social participation in the period contributed to increased social control, thus turning the state more permeable to the public interest, with an array of Democratic Participatory design.
\end{abstract}

Keywords: Social participation, Public policies, State, Society, Brazil. 


\section{APRESENTAÇÃO}

No início do século XXI, há na América do Sul um quadro inverso aquele observado ao longo da década de 1990, quando a agenda neoliberal era hegemônica na regiáo. De acordo com Coutinho (2006: 115-122) ainda que se observasse uma continuidade em alguns aspectos das políticas implementadas, as populaçóes em quase todo o continente sul-americano estariam decepcionadas com a agenda neoliberal trazida pelo Consenso de Washington e passaram a eleger novas lideranças que, no nível programático, mostravam-se mais preocupadas com a defesa dos interesses nacionais e com questóes referentes à pobreza e à desigualdade.

No Brasil foi eleito, em segundo turno nas eleiçóes de 2002, o sindicalista Luís Inácio Lula da Silva, protagonista das mobilizaçóes sociais, que marcaram a história política e social brasileira na segunda metade da década de 1970. A partir de sua liderança no movimento trabalhista foram organizadas notórias greves do ABC paulista (Santo André, São Bernardo do Campo e São Caetano do Sul), que resultaram, mais adiante, na criação do Partido dos Trabalhadores (PT), em 1979. O então candidato Lula da Silva foi eleito com o apoio do Campo Democrático e Popular ${ }^{1}$, o qual no contexto histórico da redemocratização do Brasil contribuiu para um alargamento substantivo da sociedade civil brasileira e das classes populares, e para a construção de um projeto alternativo para o país.

Eleito Presidente da República com mais de 60\% dos votos válidos, o discurso de posse de Lula da Silva ressaltava a importância do diálogo com a sociedade civil na construção de um pacto nacional para viabilizar as reformas econômicas e sociais necessárias, se comprometendo com a transparência e com o permanente estímulo à participação social. De fato, durante os dois mandatos de seu governo, um conjunto de mudanças foi colocado em marcha com o objetivo de deixar a administração pública mais democrática e permeável às demandas da sociedade.

Muitas das mudanças introduzidas caminhavam na direção da construção de um novo modelo de desenvolvimento que se opunha às orientaçóes do governo anterior, considerado alinhado com as concepçóes liberais da década de 1990, que interpretavam a crise do Estado como um excesso de Estado. Logo, para aqueles que acreditavam que o problema era o elevado tamanho, era imperativa a redução das atribuiçóes do Estado para dotá-lo

1 Em sua origem o Campo Democrático e Popular era constituído por associaçóes e movimentos comunitários, comunidades eclesiais de base, diversas pastorais da Igreja Católica, como a Pastoral da Terra e ainda por uma infinidade de grupos e movimentos sociais que se engajaram na luta pela redemocratização e pela ampliaçáo dos direitos sociais. 
de maior eficiência.

A nova coligação política no poder buscava construir um modelo de desenvolvimento no qual as demandas da sociedade fossem o foco dos objetivos da gestáo pública e da atuação da administração pública federal, incorporando a cultura política do projeto democrático participativo no aparelho do Estado.

Nesse contexto, os últimos dez anos no Brasil foram pródigos na criação de novos arranjos participativos - conselhos, conferências, mesas de diálogo, ouvidorias, audiências públicas, oficinas de participação para a elaboração do Plano Plurianual, criação de novas estruturas administrativas em atendimento às demandas de movimentos sociais, entre outras. De forma geral, todas essas medidas buscavam, em última instância, mobilizar capacidades políticas e administrativas que contribuíssem para dar sustentação ao novo modelo de gestão pública com participação social que o governo brasileiro desejava colocar em prática. No campo da gestão pública federal os avanços na participação social visavam dotar a administração pública federal de maior capacidade institucional e de maior número de ferramentas e instrumentos para ampliar a permeabilidade do ciclo de políticas públicas às demandas da sociedade.

Entretanto, a busca por uma nova proposta de reorganização para o aparelho do Estado que contemplasse a participaçáo social como elemento fundante das ações da administração pública federal mostrou-se limitada para romper com os legados deixados pelos projetos políticos de governos anteriores. De um lado, tais limites tiveram como causa as dificuldades em reverter ou reorientar instituições e mecanismos já tão enfronhados na máquina pública. De outro, os limites para implantar a gestão participativa foram motivados por certas açóes ou inaçóes governamentais da própria coligação política que defendia o projeto democrático participativo.

O objetivo principal do presente artigo é analisar os esforços realizados na última década no Brasil (2003 a 2010) na direção da ampliação da participação social nas políticas públicas federais e da elevação da efetividade dos arranjos participativos. A análise irá mostrar que os avanços na participação social ocorridos nesse período foram mais quantitativos e menos qualitativos. Isto é, as mudanças caminharam muito mais no sentido do aumento no número dos arranjos participativos existentes e de sua diversidade de formatos e de temas tratados, e menos no sentido de melhorar a qualidade das institucionalidades participativas já existentes. Entende-se aqui que o aumento da qualidade da participação se consegue por meio de espaços efetivamente públicos, isto é, que garantem a efetiva pluralidade e diversidade de seus participantes e a equivalência dos recursos 
de informação, conhecimento e poder (Dagnino, Olvera e Panfichi 2006).

Excluindo essa breve apresentação, o presente artigo encontra-se dividido em cinco partes, a saber: 1) Apresentação do debate teórico sobre a efetividade das instituições participativas; 2) os novos papéis desempenhados pelas pastas ministeriais políticas - Casa Civil da Presidência da República (Casa Civil-PR) e SG-PR a partir de 2003; 3) a estratégia de participação da sociedade na elaboração do Plano Plurianual 2004-2007; 4) a criação e ampliação de novos espaços participativos no campo das políticas públicas - Conselhos e Conferências Nacionais; 5) as consideraçóes finais.

\section{BREVE INCURSÃO NO DEBATE TEÓRICO SOBRE A EFETIVIDADE DAS INSTITUIÇÓES PARTICIPATIVAS}

Este trabalho se insere na discussão sobre a efetividade das instituições deliberativas, que surgiram em resposta ao descontentamento com os pressupostos da democracia liberal. Nesse sentido, a discussão aqui apresentada dialoga principalmente, com três grupos de estudos da tradição da Ciência Política:

1. Os que tratam das concepçóes contra-hegemônicas da democracia (participativa e deliberativa), que revelam as limitaçóes e as fragilidades das instituiçóes da democracia representativa. Habermas (1995, 1997), Pateman (1992) e Cohen e Arauto (1992) estão entre os autores mais importantes deste grupo em função de seus aportes sobre a questáo da esfera pública e a influência da sociedade civil sobre o Estado.

2. Os estudos que buscaram analisar o sucesso das instituiçóes deliberativas, isto é, se as novas instituiçôes criadas no bojo da democracia representativa, (os conselhos gestores, os orçamentos participativos, as conferências) são efetivos para influenciarem os governos na concretização de suas decisóes. Entre os estudos realizados com este propósito citam-se, os trabalhos de Lüchmann (2002), Tatagiba (2002), Lubambo e Coelho (2005) e Fung e Wright (2003).

3. Os aportes teóricos trazidos por Dagnino, Olvera e Panfichi (2006), sobre projetos políticos.

Esta seção está dividida em três partes. A primeira discute alguns aspectos da teoria habermasiana sobre a esfera pública e apresenta a discussão critica feita por alguns autores em torno da institucionalização e efetividade da esfera pública (Cohen e Arato 1992, Bohman 1996, Avritzer 2008). A segunda trata do debate mais contemporânea sobre os resultados de 
alguns estudos realizados no Brasil para avaliar os resultados de arranjos participativos. Na terceira parte, introduz-se as discussóes sobe projetos políticos.

\section{Democracia DELIBERATIVA}

O conceito hegemônico de democracia tem com base, sobretudo, as concepçóes de trazidas por Schumpeter e, posteriormente, em Dahl. Para Schumpeter "o método democrático é aquele arranjo institucional para se chegar a decisóes políticas na qual os indivíduos adquirem poder por meio da competição pelo voto do povo" (Schumpeter 1974: 269). Essa concepção de democracia é considerada minimalista ou procedimental porque reduz a relação entre governo e povo à realização dos pleitos eleitorais, ficando restrita aos procedimentos que regulam as disputas eleitorais e a participação popular fica restrita ao ato de votar. Dahl, que exerceu muita influência nos estudos sobre a democratizaçáo no contexto latino americano nos últimos vinte anos, definiu oito requisitos necessários para avaliar se o sistema de um país pode ser considerado democrático: 1) o direito de votar; 2) o direito de ser eleito; 3) a livre competição eleitoral; 4) pleitos livres e honestos; 5) liberdade de reunião; 6) liberdade de expressão; 7) pluralidade de fontes de informaçáo; 8) relação de dependência entre as açóes de governo e as eleiçóes ou outras formas de manifestação popular (Dahl 1997: 27). Para este autor, um sistema político com graus relativamente altos nestas oito condiçóes, é considerado a democracia possível. Mas, o próprio autor assevera que a exigência dessas condiçóes já dá uma ideia da distância entre a democracia possível (a democracia real) e a democracia ideal.

Em face ao descontentamento com as teorias baseadas na concepção hegemônica, no campo da teoria política contemporânea foram surgindo outras concepçóes de democracia baseadas na ideia de participação política e ampliação dos espaços públicos. As concepçóes alternativas de democracia compartilham do entendimento de que a verdadeira participação democrática será alcançada apenas a partir do alargamento do espaço da política tanto no que se refere às atividades, como na definição de quem pode participar deste campo. Nesses termos, de acordo com Laisner (2009) começa-se a discutir o procedimentalismo como prática social e não apenas como escolha de governos, surgindo às propostas alternativas de democracia participativa e democracia deliberativa.

A corrente da democracia participativa ganha impulso no meio acadêmico entre as décadas de 1960 e 1970, motivada por grande mobilização dos movimentos estudantis nos Estados Unidos e na Europa Ocidental que reivindicavam maior participação nas decisóes públicas. 
Os principais autores de referência desta corrente são Carole Pateman e C.B. Macpherson, os quais defendem que as instituiçóes e os indivíduos não devem ser vistos separadamente, em função dos efeitos psicológicos e educativos da participação. Para a corrente participacionista é possível ampliar o poder dos cidadáos sem com isso ter que diminuir o poder do Estado ou eliminar os principais institutos da democracia liberal, como a competição entre partidos pelo voto do povo e a representaçáo política. Ao invés de propor eliminar estas instituiçóes os teóricos da corrente da democracia participativa sugerem ampliar os arranjos de auto-gestáo, que são esferas localizadas na vida cotidiana dos cidadãos, como no ambiente de trabalho, na vizinhança, nos hospitais, nas escolas, entre outros, que afetam diretamente a qualidade de vida da sociedade. $\mathrm{O}$ aprendizado da participaçáo adquirido nessas instâncias capacitaria os indivíduos para atuarem com mais qualidade nas esferas políticas mais elevadas.

Por sua vez, a teoria deliberativa da democracia ${ }^{2}$ pode ser entendida como um esforço de aproximação aos antigos Ideais da soberania popular. Seus teóricos defendem que o processo de formação da vontade e da opinião da sociedade é o mecanismo que legitima a democracia. Essa corrente tem origem no pensamento de John Rawls e o de Jürgen Habermas. Rawls desenvolveu teoria da justiça, na qual vê a sociedade liberal e democrática como um sistema eqüitativo, guiado por regras e procedimentos publicamente reconhecidos e aceitos por indivíduos que cooperam e que, por isso, são beneficiados, de forma justa e apropriada.

Habermas é o principal da corrente deliberacionista e introduz o modelo de política deliberativa e procedimentalista, que se baseia nas condiçóes de comunicaçáo sob as quais o processo político visa alcançar resultados racionais. O livro Mudança Estrutural na Esfera Pública, que esse autor publicou em 1962, é considerado o marco inicial para essa discussão. Na primeira parte de sua obra, Habermas afirma que na Europa, entre os séculos XIV e XV, desenvolveu-se a esfera pública burguesa autônoma que servia de mecanismo de controle dos atos do Estado absolutista, onde desenvolvia-se a consciência crítica que articulava ideias contra a monarquia e o clero, a partir do engajamento de indivíduos em discussóes públicas que se davam em cafés, saraus ou em outros ambientes públicos frequentados pela parcela mais instruída da população.

Um importante ponto a destacar é que, de acordo Habermas (1984), predominava na esfera pública nesse período uma nítida separação entre

2 A discussão sobre a democracia deliberativa aqui apresentada não pretende ser exaustiva, pois seu objetivo é tão somente distinguir os aspectos da esfera pública habermasiana que dialogam com a discussão sobre a efetividade das instituiçóes deliberativas. 
setor público e privado. Esse autor reconhece, entretanto, que interesses econômicos começaram a dominar a esfera pública, constituindo-se em forças mais poderosas do que os discursos racionais e argumentativos, com isso iniciou-se o processo de privatização da referida esfera pública de discussão, antes livre e aberta.

Em outra obra denominada Teoria da Ação Comunicativa, Habermas reformula sua teoria social dividindo-a em esfera sistêmica e mundo da vida. E em Direito e democracia (1997), e com seu artigo "História y Crítica de la Opinión Pública: la Transformación Estructural de la Vida Pública" (1981), o autor amplia o conceito de esfera pública. Considerando o seu modelo de sociedade em dois níveis - a esfera do mundo da vida e a esfera sistêmica -, procura distinguir as origens diversas das diferentes influências que chegam à esfera pública. Destaca que a esfera pública jamais pode ser confundida com alguma instituição, organização ou qualquer estrutura normativa. Define esfera pública como rede adequada para a comunicação de conteúdos e formação de opinióes $\mathrm{O}$ autor argumenta que não é possível determinar os limites e as fronteiras da esfera pública, tampouco seus atores podem exercer poder político ou coincidir com a política institucional. Em suas palavras, "A esfera pública não pode ser entendida como uma instituição [...] Tampouco ela constitui um sistema, pois, mesmo que seja possível delinear seus limites internos, exteriormente ela se caracteriza através de horizontes abertos, permeáveis e deslocáveis" (Habermas 1997: 92).

$\mathrm{Na}$ teoria habermasiana a relação entre os processos formais e informais de formação da vontade é o que concede legitimidade ao processo democrático. $\mathrm{O}$ mecanismo de legitimação acontece na medida em que os processos informais permitem que problemas de interesse da sociedade sejam identificados, discutidos, tematizados e conduzidos às instâncias de tomadas de decisóes do sistema político. Habermas afirma que a esfera pública aparece "como uma caixa de ressonância onde os problemas a serem elaborados pelo sistema político encontram eco" (Habermas 1997: 91).

Habermas reconhece que a falta de estrutura institucional para a esfera pública diminui sua capacidade de influenciar as decisóes do sistema político formal. Mas, por outro lado, para esse autor é justamente este aspecto que concede à esfera pública maior capacidade de desempenhar seu papel de captar as novas demandas da sociedade. Nas palavras de Habermas: 
De outro lado, porém, ela (esfera publica) tem a vantagem de ser um meio de comunicação isento de limitaçóes, no qual é possível captar melhor novos problemas, conduzir discursos expressivos de autoentendimento e articular, de modo mais livre, identidades coletivas e interpretaçóes de necessidades (Habermas 1997: 32).

Nessa direção, Ribeiro (2008) afirma que, apesar de Habermas reconhecer os riscos a que uma esfera pública não institucionalizada está exposta, deixa claro que prefere a não institucionalização, entendendo que esse problema seria compensado pela dinamizaçáo do fluxo de temas da esfera privada para a pública. No entanto, para Cohen (1998), um dos principais críticos da esfera pública habermasiana, a proposta de Habermas para influenciar o legislativo e a administração pública na tomada de decisão, baseada em uma esfera pública não institucionalizada e dispersa sob a forma de uma rede de cidadãos, não encontra eco nas rotinas institucionais estabelecidas pela política moderna.

$\mathrm{Na}$ visão desse autor, para que a esfera pública seja efetiva em redefinir e influenciaros outros poderes são necessárias três condições: 1) têm de permitir e encorajar inputs que refletem experiências e preocupaçóes que podem náo ocupar a agenda normal (sensores fundamentados na experiência local e na informação); 2) devem oferecer avaliaçóes disciplinadas de propostas através da deliberação que envolvem valores políticos fundamentais; 3) precisam oferecer também ocasióes mais institucionalizadas, regularizadas para a participação dos cidadãos na tomada de decisão coletiva (Cohen 1998: 37).

Observa-se que a principal crítica de Cohen à esfera pública de Habermas reside na reduzida influência dos fluxos comunicativos sobre as decisóes tomadas pelo poder político. Este autor propóe um modelo de poliarquia diretamente deliberativa e, contrapondo-se a Habermas, volta a localizar a política nos arranjos institucionais que estruturam a organização do poder nas democracias modernas. Ou seja, sua proposta pressupóe a existência de mecanismos institucionais que regulam o funcionamento da esfera pública, tornando obrigatório o reconhecimento dos resultados alcançados no processo de deliberação, por meio do qual aumentam a influencia sobre os poderes oficialmente estabelecidos (Ribeiro 2007: 41)

Bohman, em seu livro Public Deliberation, apresenta outra proposta de funcionamento da esfera pública, para o qual "[...] a deliberação pública [é] um processo dialógico de troca de razóes com o objetivo de solucionar situaçôes problemáticas que não encontrariam resolução sem a coordenação e a cooperação entre as pessoas" (Bohman 1996, apud Avritzer 2000: 42). Bohman faz uma tentativa de integrar elementos dialógicos com concepção 
de razão pública e, ao mesmo tempo, de integrar os públicos informais com algum elemento capaz de institucionalizar a deliberação pública. Nesse sentido, vai além de Habermas ao criticar os limites da influência do público no sistema político. Entende que a deliberação ocorre na medida em que os participantes em atividades conjuntas reconhecem que eles influenciaram e contribuíram para que certos desfechos ocorressem. Bohman transforma a influência quase fictícia dos públicos no sistema político em influência real (Avritzer 2000: 25)

Como se observa, as críticas de Cohen e Bohman à formulação de Habermas têm como foco a operacionalização do conceito de esfera pública, buscando novos formatos e mecanismos capazes de ampliar a efetividade de sua atuação. Avritzer (2000: 26), por sua vez, também faz coro às críticas de Cohen e Bohman no tocante aos problemas derivados da ausência de institucionalização da esfera pública habermasiana, afirmando que a forma e os locais ideais da institucionalização da deliberação pública deveriam ser os fóruns entre o Estado e sociedade que têm surgido em países tão diferentes quanto o Brasil, a Índia e os Estados Unidos.

Para esse autor, no Brasil esses fóruns seriam os conselhos e o orçamento participativo porque reúnem três condiçóes ou características que são centrais para que ocorra a argumentaçáo deliberativa: 1) há cessão por parte do Estado de um espaço decisório em favor de uma forma ampliada e pública de participação. Ou seja, o Estado viabiliza as condiçôes para o funcionamento de um formato institucional onde interesses distintos podem argumentar sobre as suas posiçóes; 2) as informaçóes relevantes para uma deliberação de governo são tornadas públicas ou socializadas, partindo do princípio de que o Estado possui informaçóes incompletas para a tomada de decisóes e que, portanto, é preciso que os atores sociais tragam informaçóes para que a deliberaçáo contemple plenamente os problemas políticos envolvidos; 3) há possibilidade de testar múltiplas experiências e existência de uma diversidade de variação nos arranjos e na forma de compartilhar as decisões.

A breve discussão sobre a esfera pública de Habermas aqui apresentada buscou chamar atençáo para duas chaves importantes que são comuns aos textos críticos apresentados: 1) ambos apontam para a mesma preocupação relacionada à efetividade, no sentido de dotar a esfera pública habermasiana de operacionalidade procedimental a fim de que suas decisóes gerem consequências legislativas e administrativas; 2) todas as soluçôes apresentadas consideram que é necessária a institucionalização da esfera pública para melhorar sua capacidade de influenciar os poderes oficialmente constituídos. A discussão sobre institucionalização dos espaços públicos também coloca em evidência a preocupação dos autores 
vinculados à corrente deliberacionista com a qualidade dos processos deliberativos, ou seja, em procurar avaliar se os novos arranjos participativos têm conseguido cumprir sua função deliberativa, pautando as decisóes do Estado por meio de sua atuação.

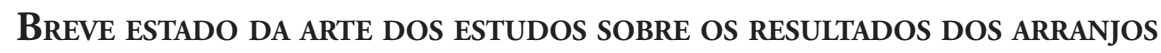 DELIBERATIVOS NO BRASIL}

A literatura que analisa os resultados da participação social na produção de políticas públicas tem trazido avanços significativos na revelação de alguns fatores que podem ser responsáveis para os sucessos ou insucessos no funcionamento de determinados arranjos participativos municipais. Entretanto esses estudos avançam muito pouco na problemática dos fatores que determinam à maior ou a menor influência da participação social na produção de políticas públicas nacionais e em como e sob quais condiçóes a influência da sociedade que ocorre por meio dos espaços participativos é afetada por determinados fatores. Em relação aos estudos realizados com esse propósito citam-se, entre outros, os trabalhos de Lüchmann (2002), Tatagiba (2002), Lubambo e Coelho (2005) e Fung e Wright (2003), que destacam alguns fatores que são importantes para os resultados alcançados pelos arranjos participativos.

Lüchmann (2002) estuda o orçamento participativo no município de Porto Alegre, Brasil, e identifica alguns fatores responsáveis pelo sucesso desse modelo, destacando o desenho institucional ao lado de outros como a vontade política e a tradição associativa local. No seu trabalho a autora reconhece a importância do projeto político-partidário e do comprometimento governamental com a viabilização da experiência participativa. Sugere, no entanto, que é a participaçáo do associativismo local o fator que exerce maior influência na nova dinâmica de construção do orçamento público com participação dos cidadãos.

Já o trabalho de Tatagiba (2002) analisa os conselhos municipais de assistência social, saúde e defesa de direitos e realiza meta-avaliação de um conjunto de estudos realizados por autores diferentes com o objetivo de entender o funcionamento destes conselhos. Em sua análise a autora conclui que os conselhos gestores municipais apresentam reduzido poder de influência no processo de definição de políticas. Entre os fatores que contribuem para os resultados pouco significativos dos arranjos participativos a autora ressalta a baixa representatividade dos conselheiros náo-governamentais; a fragilidade nos vínculos entre estes e as suas bases de origem; a falta de qualificação dos conselheiros para o exercício dos seus papéis; e a baixa capacidade propositiva dos conselhos. Tatagiba (2002) também chama atenção para a elevada influência do projeto político na 
qualidade dos resultados alcançados pelos conselhos gestores municipais. Para essa autora o excesso de controle governamental sobre os conselhos "coloca muitas dúvidas a cerca das reais condiçôes de estes virem a exercer sua vocaçáo deliberativa, que costuma depender da importância que o projeto político do governo, em cada caso específico, confere ao princípio de participação social" (Tatagiba 2002: 98).

A análise de Lubambo e Coelho (2005) trata das estratégias de participação implementadas pelos atores sociais nos estados de Pernambuco e Rio Grande do Sul, considerando os fatores relacionados à cultura política e aos condicionantes institucionais e políticos para a participação e para o empoderamento da população em diferentes regióes do país. De acordo com as autoras as dificuldades maiores de empoderamento são proporcionais à resistência da sociedade à participação. Tal resistência seria resultado de uma herança cívica desfavorável presente em muitas regióes brasileiras e pequenos municípios do Norte e do Nordeste do Brasil. Nessas localidades evidenciam-se os fatores limitantes da participaçáo social na vida do Estado, convivendo, de um lado, com governos descomprometidos com a transparência e o bem-estar da população e, de outro, baixo capital social devido às reduzidas experiências locais de associativismo.

Finalmente, Fung e Wright (2003) atribuem ao desenho institucional à capacidade de gerar êxito aos processos participativos e propóem a repetição de desenhos independentemente de contexto. Destacam que a participação ampla e profunda ocorre quando se estabelecem canais de participação em áreas de interesses das pessoas e quando o desenho institucional dos canais de participação é capaz de estimular a participação., desestimulando as formas clientelistas de relação com o Estado.

As diferentes contribuiçóes citadas sobre os fatores que interferem na capacidade dos arranjos participativos em influenciarem o processo de produção de políticas públicas demonstram que a literatura e o debate corrente oferecem diversas explicaçóes para compreender a força e a fraqueza das institucionalidades participativas. Expóem-se fatores institucionais, tais como o conjunto de procedimentos institucionalizados que possibilita a participação e a representação paritária no processo das políticas. Sobre isso, em seu trabalho Lüchmann assevera que "em se tratando de uma perspectiva democrática deliberativa, pensar a institucionalidade significa pensar em uma construção institucional pautada em mecanismos democráticos de garantia dos princípios de igualdade, pluralismo e liberdade" (Lüchmann 2002: 51). Também é o caso de Fung e Wright (2003) que afirmam que o problema não está nas tarefas das instituiçôes e sim em seus desenhos institucionais. 
Já outros estudos colocam mais peso nos aspectos da representatividade dos conselheiros, especialmente na relação com as entidades que representam (sociedade civil) e nas dificuldades de conciliação de interesses e negociaçáo entre os atores que participam de determinado espaço participativo. Tal é o caso do Estudo de Tatagiba (2002), que chama atenção para o aspecto da fragilidade existente na relação entre os conselheiros governamentais e os não governamentais e destes com a sua atuação nos conselhos municipais. No tocante aos conselheiros governamentais as ideias que estes defendem no âmbito destes arranjos não resultam de posiçóes oficiais das agências estatais que representam, mas sim refletem suas próprias opinióes. Do lado dos conselheiros não governamentais este mesmo problema se reproduz, na medida em que as posiçóes defendidas não são discutidas com suas entidades de origem.

Lubambo e Coelho (2005) fazem a ponte entre os aspectos políticos e institucionais, que atuam limitando o maior envolvimento da população nos processos associativos nas diferentes regióes do país. Esses autores destacam, de um lado, os limites contidos na representação e na participação popular intermediada por associaçóes de qualquer espécie despreparadas para enfrentar os problemas que surgem nas açóes coletivas, e, de outro, os limites das burocracias que funcionam de acordo com modelos que seguem as práticas clientelistas e patrimonialistas.

\section{Projetos políticos E a efetividade dos arRanjos participativos}

Dagnino, Olvera e Panfichi, (2006), definem projeto político como os conjuntos de crenças, interesses, concepçóes de mundo, representaçóes do que deve ser a vida em sociedade, que orientam a açáo política dos diferentes sujeitos. Esses autores identificam três projetos políticos na América Latina, que guardam grandes diferenças entre si, quanto à forma e ao conteúdo da democracia que defendem. Esses projetos políticos são denominados de: 1) autoritários; 2) neoliberal; 3) democráticoparticipativo. Esses autores consideram que o reconhecimento e a identificação dos conteúdos dos diferentes projetos políticos e suas formas de implementação são fundamentais para distinguir as matizes do projeto democrático participativo, constituído a partir das lutas contra o projeto autoritário, do projeto neoliberal, que incorpora todo um discurso participativo, mas com significados diferentes.

Conforme destaca Tatagiba (2003: 16), os princípios da participação ganham contornos muito diferenciados, dependendo dos estilos de gestão dos governos aos quais estão subordinadas as experiências participativas. De acordo com essa autora a investigação acerca do significado da participação diz muito sobre a direção do projeto democrático em curso: 
Por isso interrogamos a cerca dos significados que a participação assume e, principalmente, das tendências que consolida é condição importante para compreendermos a natureza da democracia em construçáo. Isso quando partimos do suposto de que a participaçáo pode ajudar a consolidar tendências distintas, seja na direção da ampliaçáo/aprofundamento da democracia, seja na redução da sua intensidade e escopo (Tatagiba 2003: 21)

Nesse contexto é importante resgatar a discussão trazida por Dagnino $(2002,2004,2006)$ sobre a confluência perversa que reflete a disputa entre o projeto neoliberal, cujo eixo estruturante é a implementação das medidas de ajustes dos estados latino-americanos, partindo de um receituário liberal, e o projeto democrático participativo, que, no Brasil, tem como marco fundamental as lutas dos movimentos sociais pela ampliação dos direitos sociais e pelo aprofundamento da democracia. Este artigo compartilha do entendimento dessa autora de que há uma disputa político-cultural entre esses dois projetos que confundem e deslocam o sentido de três noçóes: sociedade civil, participação e cidadania.

Dagnino (2004) chama atenção para a importância de se examinar com cuidado as distinçóes e divergências fundamentais que existem entre os projetos neoliberal e democrático-participativo:

A coincidência na exigência de uma sociedade civil ativa e propositiva, que estes dois projetos antagônicos apresentam, é, de fato, emblemática de uma série de outras "coincidências" no nível do discurso, referências comuns que, examinadas com cuidado, escondem distinçóes e divergências fundamentais. Assim, o que essa "confluência perversa" determina é um obscurecimento dessas distinçôes e divergências, por meio de um vocabulário comum e de procedimentos e mecanismos institucionais que guardam uma similaridade significativa (Dagnino 2004: 201).

A análise dos avanços na participação social do Brasil, que resultaram na criação de novos arranjos participativos e no fortalecimento dos já existentes, requer considerar as matizes dos projetos políticos que lhes dão sustentação a fim de observar as concepçôes de sociedade civil, participação e cidadania que embasam seus objetivos. Além disso, é importante explorar mais detidamente os núcleos duros do projeto democrático-participativo, que são as noçóes de direitos e de espaços públicos. Esses últimos só podem ser considerados efetivamente públicos se puderem garantir a equivalência de seus recursos de informaçáo, conhecimento e poder (Dagnino, Olvera e Panfichi 2006). 
Por sua vez, em Projetos Politicos e Arranjos Participativos Nacionais no periodo 2003-2010, Rocha (2013) estuda as razóes que fazem com que os arranjos participativos apresentem diferentes capacidades de influenciar os atores governamentais e, com isso, de conseguirem fazer valer suas contribuiçôes na direção da efetivação dos direitos previstos na política pública que é objeto de suas deliberaçóes. O estudo analisa os atributos dos arranjos participativos que afetam o funcionamento e a qualidade de atuaçáo dos mesmos e que são representativos dos dois projetos políticos em disputa: democrático-participativo e neoliberal. Os atributos analisados são: 1) a pluralidade da participação; 2) o papel da sociedade civil; 3) a existência de recursos para aumentar a força das decisóes; 4) a incidência das resoluçóes no ciclo de políticas publicas. Rocha (2013) conclui que os traços predominantes de diferentes projetos políticos encontrados em conselhos nacionais de politicas públicas condicionam seu desenho institucional, sua atuação, e seu funcionamento, amplificando ou reduzindo a capacidade desses espaços participativos em exercerem influencia na atuação governamental.

O alargamento dos espaços de participação da sociedade, que teve lugar no período de 2003 a 2010, foi impulsionado pelo campo éticopolítico do projeto democrático-participativo que tentou trazer para a esfera da política nacional as experiências participativas que já haviam sido introduzidas em governos locais pelo partido politico que representa esse projeto no Brasil. As seçóes seguintes tratarão de demonstrar os desafios, os avanços e as dificuldades enfrentadas por diferentes arranjos participativos, encontrados no âmbito do governo central do Brasil, para tornarem-se mais efetivos no sentido de conseguirem fazer valer suas decisóes.

\section{MUDANÇA NA ÁREA POLÍTICA DA ESTRUTURA GOVERNAMENTAL: CRIAÇÁO DE INTERLOCUÇÃO COM A SOCIEDADE CIVIL NA PRESIDÊNCIA DA REPÚBLICA}

A nova coligação política no poder buscava construir um modelo de desenvolvimento no qual as demandas da sociedade fossem o foco dos objetivos da gestão pública e da atuação da administração pública federal, incorporando a cultura política do projeto democrático participativo no aparelho do Estado. Com esse propósito, uma das primeiras medidas implementadas foi a mudança no arranjo institucional da Secretaria-Geral da Presidência da República (SG-PR). A análise das mudanças introduzidas nas pastas políticas a partir de 2003 mostra que as novas atribuiçóes conferidas à SG-PR são, de longe, aquelas que mais ilustram a disposição da nova coligaçáo política no poder em dialogar com representantes da sociedade, desde às áreas administrativas mais próximas ao Presidente da 
República.

Até 2002 a SG-PR tinha atribuiçóes meramente administrativas. A partir de 2003, no então governo de Lula da Silva, como pode ser constatada pelas informaçóes contidas no Tabela 1, a SG-PR passou a ser o lócus estratégico da articulação social entre governo e sociedade. Por meio de decreto presidencial, esse órgão recebeu a atribuição de assistir direta e imediatamente ao Presidente da República no desempenho de suas atribuiçóes, especialmente no relacionamento e diálogo com as entidades da sociedade civil e na criação de instrumentos de consulta e participação popular de interesse do Poder Executivo.

De forma geral, a SG-PR se organizava internamente a partir do funcionamento de duas subsecretarias: 1) a Secretaria Nacional de Articulação Social, com as atribuiçóes de coordenar e articular as relaçóes políticas do Governo com os diferentes segmentos da sociedade civil; e de propor a criação, promover e acompanhar a implementação de instrumentos de consulta e participação popular de interesse do Poder Executivo; 2) a Secretaria de Estudos e Pesquisas Políticos-Institucionais, com as atribuiçóes de planejar, organizar e acompanhar a agenda do Presidente da República com os diferentes segmentos da sociedade civil; produzir análises de políticas públicas e temas de interesse do Presidente da República. $\mathrm{Na}$ prática, essa última subsecretaria, composta majoritariamente por um quadro de militantes do Partido dos Trabalhadores oriundo de diferentes estados do país, organizava as diferentes agendas políticas dos eventos com a participação do Presidente. Atuava de forma a incentivar a mobilização de segmentos sociais, quando de uma agenda do presidente da república nas diferentes unidades da federação e também, quando era necessário, seu quadro funcional agia desmobilizando manifestaçóes consideradas indesejadas ao presidente da república. Tudo isso era conseguido graças à penetração que os militantes dessa Subsecretaria tinham nas diferentes organizaçôes da sociedade. Essa equipe era conhecida como Escaláo Avançado Presidencial (Escave), cuja missão era assegurar as condições adequadas para o êxito político-institucional das missões presidenciais.

Para ser Ministro da SG-PR foi escolhido um dirigente do Partido dos Trabalhadores, que havia sido, em 1982, deputado federal da primeira bancada do PT na Câmara Federal e trazia em sua trajetória política a militância no movimento sindical dos professores e trabalhadores na educação no Rio de Janeiro e em Minas Gerais. Juntamente com Lula e outros dirigentes sindicais e cofundador da Central Única dos Trabalhadores. Para melhor compreender a dimensão das mudanças realizadas no arranjo institucional da Presidência da República a partir de 2003 é pertinente a comparação com a estrutura da Presidência da Republica instalada a partir 
do inicio do governo anterior, em 1995.

Observa-se no Tabela 1 que em 1995, a estrutura administrativa da Presidência da República apresentava desenho voltado, prioritariamente, para possibilitar o diálogo com os poderes legalmente instituídos, como o Congresso Nacional e os estados e municípios. A SG-PR, na década de 90, detinha atribuiçôes administrativas de suporte ao Gabinete do Presidente da República. Por sua vez, a Casa Civil-PR, outro importante órgão da estrutura da PR, se incumbia da articulação política com o Congresso Nacional, com os entes federados e com a ação governamental. Observase que, apesar de entre as atribuiçóes da Casa Civil-PR, em 1995, constar a de relacionar-se com a sociedade, o único conselho com participação de pessoas da sociedade existente na estrutura da Presidência era o da Comunidade Solidária. Esse era presidido pela Primeira Dama do país, uma antropóloga renomada, Ruth Cardoso e tinha, entre suas atribuiçôes, a de articular-se com a sociedade civil, à época chamada pela própria antropóloga de terceiro setor.

\section{Tabela 1: Estrutura comparada da Presidência da República, Janeiro de 1999 e Janeiro de 2003}

Janeiro de 1995

Órgãos de assessoramento imediato ao PR
1. Conselho de Governo

2. Advocacia-Geral da União

3. Alto Comando das Forças Armadas

4. Estado-Maior das Forças Armadas
1. Conselho de Governo

2. Conselho de Desenvolvimento Econômico e Social

3. Conselho Nacional de Segurança Alimentar e -

Nutricional

4. Conselho Nacional de Política Energética

5. Conselho Nacional de Integração de Políticas de -

Transporte

6. Advogado-Geral da Uniáo;

7. Assessoria Especial do Presidente da República

8. Secretaria de Imprensa e Divulgaçáo da PR

9. Porta-Voz da PR

Órgãos de Consulta do Presidente da República

1. Conselho da República

1. Conselho da República

2. Conselho de Defesa Nacional

2. Conselho de Defesa Nacional 
Janeiro de 1995

janeiro de 2003

Órgãos Integrantes da Estrutura da Presidência da República

1. Casa Civil-PR

Atribuiçóes: assistir direta e imediatamente ao Presidente da República no desempenho de suas atribuiçóes, especialmente na coordenaçáo e na integracáo da ação do governo, na verificação prévia da constitucionalidade e legalidade dos atos presidenciais, no relacionamento com o Congresso Nacional, com os demais niveis da Administração Pública e com a sociedade.

Órgãos subordinados à Casa CivilPR

- Conselho do Programa Comunidade Solidária

- Gabinete

- Subchefia-Executiva

- Subchefia para Assuntos Parlamentares

- Subchefia de Coordenação da Açáo Governamental

- Subchefia para Assuntos Jurídicos

- Subchefia de Relaçóes Intergovernamentais

\section{SG-PR}

Atribuições: assistir direta e imediatamente ao Presidente da República no desempenho de suas atribuiçóes, especialmente $\mathrm{Na}$ supervisão e execução das atividades administrativas da Presidência da República.

3. Secretaria de Comunicação Social da PR

4. Secretaria de Assuntos

Estratégicos da PR

5. Casa Militar da PR

\section{Casa Civil-PR}

Atribuiçóes: assistir direta e imediatamente ao Presidente da República no desempenho de suas atribuiçôes, especialmente na coordenação e na integração das açóes do Governo, na verificaçao prévia da constitucionalidade e legalidade dos atos presidenciais, na análise do merito, da oportunidade e da compatibilidade das propostas com as diretrizes governamentais, realizar a coordenação política do Governo, o relacionamento com o Congresso Nacional e os partidos políticos, a interlocuçáo com os Estados, o Distrito Federal e os Municipios, bem como promover a publicaçáo e preservaçáo dos atos oficiais e supervisionar e executar as atividades administrativas da Presidência da República e supletivamente da Vice-Presidência da República.

Órgãos Subordinados à Casa Civil-PR

- Conselho Deliberativo do Sistema de Proteção da Amazônia,

- Conselho Superior de Cinema

- Arquivo Nacional, a Imprensa Nacional,

- Gabinete,

- Secretaria Executiva

- Subchefia de Assuntos jurídicos

- Subchefia de Assuntos Parlamentares

- Subchefia de Açáo Governamental

- Subchefia de Assuntos Federativos

- Orgão de Controle Interno.

2. SG-PR

Atribuiçôes: assistir direta e imediatamente ao Presidente da República no desempenho de suas atribuiçóes, especialmente:

- No relacionamento e articulação com as entidades da sociedade civil

- Na criação e implementação de instrumentos de consulta e participaçáo popular de interesse do Poder Executivo.

- Na Elaboracáo da agenda futura do Presidente da República.

- Na preparação e formulação de subsídios para os pronunciamentos do Presidente da República.

- Na promoçáo de análises de políticas públicas e temas de interesse do Presidente da República.

- Na realização de estudos de natureza político-institucional e outras atribuiçóes que lhe forem designadas pelo Presidente da República.

3. Secretaria de Comunicação de Governo e Gestão Estratégica da PR

- Controladoria-Geral da União

- Secretaria Especial de Políticas para as Mulheres

- Secretaria Especial de Aquicultura e Pesca

- Secretaria Especial dos Direitos Humanos

- Secretaria Especial de Políticas de Promoção da Igualdade Racial 
Como se observa, a partir de 2003, as mudanças na estrutura administrativa da Presidência da República coloca a sociedade civil mais próxima dos principais assessores do Presidente. É bem verdade que grande parte dos dirigentes que ocuparam cargos no primeiro escaláo do governo de Lula da Silva tinha uma história de militância em partidos e/ ou em organizaçóes da sociedade civil esse perfil pode ter facilitado essa proximidade.

\section{A qualidade na participação no novo espaço na Presidência da REPÚBLICA}

Para avaliar a qualidade do novo espaço de participação da sociedade aberto no âmbito da SG-PR, seria necessário pesquisar se os encaminhamentos resultantes do diálogo social realizado por este órgão tiveram consequência administrativa, o que demandaria uma análise mais aprofundada que extrapola o escopo do presente artigo.

No entanto, a título de reflexão, pode-se indagar sobre qual era o espaço de poder técnico e político reservado à SG-PR para encaminhar as demandas da sociedade aos escaninhos apropriados da burocracia federal. Também é pertinente indagar sobre o poder de negociação da SG-PR em emplacar uma demanda da sociedade civil junto aos órgãos decisórios de políticas públicas do governo federal, como são a Casa Civil-PR, o Ministério da Fazenda ou o Ministério do Planejamento.

O que se sabe a respeito é que algumas demandas da sociedade que contrariavam, por exemplo, o Programa de Aceleração do Crescimento (PAC), conduzido pela Casa Civil-PR, encontravam reduzida margem de negociação para serem atendidas. Dessas, servem como exemplos os projetos polêmicos como a transposiçáo do rio São Francisco, a construçáo das duas usinas hidroelétricas do rio Madeira, que apesar das intensas mobilizaçóes contrárias da sociedade civil, seguiram sendo implementados.

Um exemplo de embate entre a SG-PR, o Ministério da Fazenda e o do Planejamento, que ilustra as dificuldades da SG-PR junto aos órgãos decisórios de políticas públicas, refere-se à reivindicação de setores da sociedade civil do campo das organizaçóes náo governamentais de terem acesso ao Sistema de Administração Financeira (Siafi) para exercerem, com mais qualidade, o acompanhamento do gasto federal. Essa demanda sempre contou com o apoio da SG-PR, que chegou a se comprometer com prazos e formas de fornecimento de senhas para o acesso a esse sistema por parte de setores da sociedade civil. No entanto, nem o Ministério da Fazenda e tampouco o Ministério do Planejamento concordavam em conceder o acesso desse Sistema para a sociedade. 
Apesar das reiteradas promessas da SG-PR, a sociedade seguiu até o final do governo Lula da Silva sem o acesso ao Sistema de Administração Financeira (Siafi). De um lado, os representantes da sociedade defendem que precisam ter a mesma informaçáo que os gestores e os servidores públicos a fim de conseguirem exercer com qualidade o controle social. De outro, os técnicos governamentais dos ministérios da Fazenda e do Planejamento argumentam que as informaçôes do Siafi são gerenciais e não devem ser de acesso amplo, principalmente porque seus dados e números são de difícil entendimento para a população em geral.

A análise sobre a efetividade do novo papel da SG-PR entre os anos de 2003-2010 está longe de ser conclusiva. Apesar das dificuldades e de sua reduzida margem de negociaçáo junto aos seus pares do governo federal, é possível afirmar que o novo papel da SG-PR no governo Lula da Silva contribuiu para reforçar a cultura democrática participativa no governo federal por meio da abertura de diálogo com sociedade civil.

As novas atribuições da SG-PR, a partir de 2003, são exemplos de inovação associada ao Projeto Democrático Participativo, pois tentou estabelecer nova relação Estado-sociedade, confrontando-se com a cultura política do projeto político do governo anterior. Importante lembrar que a partir de 1995, a administração pública federal começou a incorporar as ferramentas da New Public Management, que reserva às decisóes sobre as políticas públicas a um núcleo técnico estratégico localizado à alta burocracia, onde não há lugar para incluir as contribuiçóes da sociedade. Tal traço, característico do projeto político do governo anterior dificultou a introdução do novo método de governabilidade social no seio da burocracia federal.

Assim, as inovaçôes introduzidas no Executivo federal, no período 2003-2010, destacando-se o novo papel da SG-PR, trouxeram, com certeza, mudanças na cultura política da burocracia publica federal. O novo papel desempenhado pela SG-PR de valorizar a participação social desde a alta cúpula política da administração pública federal despertou para a necessidade de desenvolver novos valores participativos junto aos demais dirigentes e aos servidores públicos que se ocupam da elaboração e da execução de políticas públicas no governo federal. O diálogo com a sociedade e movimentos sociais passou a ressoar como uma orientação vinda do presidente da república e como um valor importante a ser incorporado pela burocracia. É claro que valores não são mudados tão facilmente, mas, mesmo que no início parte da burocracia mude seu modus operandis apenas para seguir as orientaçóes emanadas da hierarquia superior, esta já é o início da mudança almejada. 
Ainda analisando o novo papel da SG-PR, apesar de reconhecer seus efeitos positivos sobre o comportamento da burocracia federal, não é possível deixar de ressaltar suas limitaçóes de poder quando se trata de encaminhar as demandas da sociedade para o âmbito interno do governo. Isto é fato, sobretudo, quando tais demandas impactam em questóes consideradas maiores, incluídas no campo do debate econômico e da distribuição de renda.

Sendo assim, pode-se afirmar que o novo papel da SG-PR, embora no campo das ideias e princípios esteja em consonância com o projeto democrático participativo, não conseguiu mudar a relação Estado-sociedade em todas as suas ações. Suas ideias e inovações enfrentaram inúmeras dificuldades para fazer do diálogo social uma prática na burocracia federal. Não houve compartilhamento de poder em importantes discussôes que afetam a vida da população e não houve paridade na participação. Mas, apesar dos enfrentamentos dentro e fora do governo, a estratégia da SGPR coleciona algumas vitórias conseguidas a partir da prática do diálogo. Dentre essas, cita-se, a título de exemplo, a experiência inédita, no Brasil, de diálogo e negociação nacional tripartite para enfrentar o desafio de melhorar as condiçóes de vida e trabalho no cultivo manual da canade-açúcar. Esse compromisso foi construído por meio de uma Mesa de Diálogo, instalada em 2008, sob a coordenação da SG-PR. Ao longo de um ano, a Mesa construiu um acordo histórico para valorizar e disseminar as melhores práticas trabalhistas na lavoura da cana-de-açúcar e promover a reinserção ocupacional dos trabalhadores desempregados pelo avanço da mecanização da colheita.

\section{PARTICIPAÇÃO SOCIAL NA ELABORAÇÃO DO PLANO PLURIANUAL 2004-2007 DO GOVERNO FEDERAL}

No Brasil, o Plano Plurianual (PPA) é um documento constitucional que sintetiza a orientação estratégica de um governo, contempla as diretrizes do modelo de desenvolvimento que será adotado e inclui os programas, que constarão dos orçamentos anuais da União para os próximos quatro anos subsequentes a sua elaboraçáo. Elabora-se um PPA no primeiro ano de exercício do novo mandato presidencial e, como esse documento abarca um período de quatro anos, suas orientaçóes continuam vigentes até o primeiro ano de mandato do próximo governante eleito. Sendo assim, todo Presidente da República herda, em seu primeiro ano de governo, um PPA elaborado pelo governo anterior. O objetivo dessa periodizaçáo imposta pela legislação é fazer com que haja continuidade dos projetos na transição de um governo para outro. 
São três os instrumentos legais definidos constitucionalmente relativos ao ciclo orçamentário: o primeiro é o Plano Plurianual (PPA), que define um plano de médio prazo, com os programas e açóes estabelecidos para o período de governo de quatro anos, o segundo é a Lei de Diretrizes Orçamentárias (LDO), que estabelece as metas e prioridades para o terceiro instrumento, que é a da Lei Orçamentária Anual (LOA), referente ao exercício seguinte, esta seguindo estas diretrizes estabelecerá de forma detalhada todas as receitas e despesas relativas ao Orçamento Geral da União.

A iniciativa de elaborar um PPA no Executivo federal com participação social já havia sido anunciada desde a época de campanha para presidente do entáo candidato Lula da Silva. A ideia era trazer a experiência de participação popular na elaboração de orçamentos públicos - uma marca de administraçóes petistas municipais e estaduais - ao governo federal. A participação da sociedade nos processos de elaboração e gestão dos PPAs, das Leis de Diretrizes Orçamentárias - LDOs e dos orçamentos anuais da Uniáo LOA encontram amparo legal no parágrafo único do artigo 48 da Lei Complementar N. ${ }^{\circ}$ 101, de 4 de maio de 2000. Essa norma prevê que a transparência da gestáo fiscal deve ser assegurada, também, mediante incentivo à participação popular e à realização de audiências públicas, durante os processos de elaboração e de discussão dos planos, Lei de Diretrizes Orçamentárias e orçamentos.

AS EXPECTATIVAS EM TORNO DA PRIMEIRA EXPERIÊNCIA FEDERAL DE ELABORAÇÃO PARTICIPATIVA DO PLANO PLURIANUAL

As expectativas das organizaçóes da sociedade e de representantes do Governo Federal em relação à participação da sociedade no PPA eram bastante otimistas quanto aos resultados. Vislumbravam a possibilidade de compartilhar com o governo federal das decisóes sobre o modelo de desenvolvimento do país e da elaboraçáo das políticas e programas governamentais mais inclusivas e voltadas para a população historicamente excluída. O processo de consulta da população ao PPA 2004-2007 obedeceu a uma sequencia de etapas, cuja observação demonstra o protagonismo de setores da sociedade civil vinculados à Associação Brasileira das Organizaçôes Não Governamentais (ABONG), bem como a importante participação de representantes governamentais, principalmente da SG-PR. Essa última, como explicado anteriormente, era o órgáo encarregado da articulação com os movimentos sociais no governo em curso no período 2003-2010.

Para garantir a participação da sociedade na elaboração do PPA foram organizadas e realizadas consultas públicas estaduais das quais 
participavam os sindicatos, as organizaçôes não governamentais, as igrejas, os grupos empresariais, as organizaçóes de gênero, raça, indígenas, pessoas com deficiência, representantes de outras orientaçôes sexuais, associaçóes de bairro e instituiçóes acadêmicas. A estrutura geral das oficinas, que ocupavam um dia de trabalho, dividia-se em quatro etapas: 1) apresentação de um vídeo do PPA; 2) apresentação do PPA por um ministro de Estado; 3) divisão dos participantes para os trabalhos em grupos e 4) apresentação dos encaminhamentos. No total, cerca de 4.000 pessoas, representando 2.170 entidades, estiveram presentes nas consultas públicas realizadas.

\section{Breve avaliaçáo do processo de participaçáo social no PPA 2004- $2007^{3}$}

A consulta à sociedade deu-se no nível estratégico do PPA. Isto é, na primeira fase da elaboração do PPA, então denominada Orientaçóes Estratégicas. A sociedade participou sobre o que deveriam ser as grandes prioridades nacionais. Essas prioridades seriam desdobradas nas etapas seguintes em políticas públicas, programas e açóes governamentais. Entretanto, é importante esclarecer que a sociedade não foi consultada nas demais etapas de construçáo do PPA. Neste ponto, é importante marcar uma diferença sobre o que se consulta no âmbito nos processos de orçamentos participativos nos municípios. Neste último, a consulta recai sobre a alocaçáo dos recursos orçamentários em programas. Ou seja, a população opina nas dimensóes mais concretas do ciclo de políticas públicas, enquanto que no processo de participação social que teve lugar no governo federal para a elaboração do PPA 2004-2007, a participaçáo se deu nas dimensóes mais distantes da realidade da populaçáo.

Para representantes da sociedade civil o processo de participação social do PPA 2004-2007 envolveu a sociedade apenas em questóes periféricas relacionadas aos mega-objetivos das orientações estratégicas (Moroni 2006: 16). Para Moroni (2006), como a sociedade civil não pode participar da etapa das diretrizes sociais, nada pode ser feito para tentar mudar a lógica das políticas públicas, essa sim, na visão desse autor, teria sido a principal mudança na lógica de elaboração do Plano. A busca de explicação para o reduzido sucesso desse processo participativo evidencia alguns problemas no método adotado e no processo de condução, destacando-se, dentre outros, os seguintes:

1. Objeto de consulta distante do cotidiano da população, pois não se consultava sobre recursos orçamentários e prioridades para programas e políticas concretas, e sim sobre desafios e megaobjetivos, considerados

3 Para ver análise mais detalhada sobre esse tópico consultar Rocha (2013). 
abstratos por muitos.

2. Inflexibilidade constitucional do prazo para elaboração e entrega do PPA ao Congresso Nacional. Na prática, essa dificuldade se traduziu na dificuldade de aproveitamento de inúmeras sugestôes da sociedade, pois muito provavelmente no momento da realização de algumas consultas estaduais, que aconteceram no mês de julho, a burocracia do Ministério do Planejamento, responsável pela elaboração do Plano, se encontrava nas etapas de finalização do mesmo, que deveria ser entregue ao Congresso Nacional, impreterivelmente, até 31 de agosto daquele ano (2003).

3. Dificuldade de continuidade da participação social ao longo do processo do ciclo de políticas públicas.

Desde o início da mobilização para a participação social no PPA 20042007 estava claro que a demanda da sociedade era a participaçáo em todo o ciclo orçamentário, que envolve o planejamento, o processo de alocação de recursos, a implementação física e financeira das políticas e programas. Entretanto, o processo de participaçáo em referência ficou restrito à etapa das consultas aos grandes desafios, tornando difícil prestar contas à sociedade de onde e como suas sugestóes foram incorporadas.

A discussáo e a consulta à sociedade se deram em torno dos megaobjetivos das orientaçóes estratégicas do Plano, os quais trazem questóes que se localizam em uma esfera muito distante do cotidiano da vida das pessoas. É de se observar que a populaçáo consultada reside em um município, têm filhos em determinada escola, utilizam determinado posto de saúde, ou seja, a preocupação mais próxima e quanto à entrega, que são materializadas nos resultados das políticas públicas implementadas pelo Estado. Por esta ótica é compreensível que a expectativa da participação resultasse em melhoria dos equipamentos públicos, ampliação do acesso aos direitos sociais às políticas públicas implementadas localmente. No entanto, na metodologia de participação adotada para o PPA 2004-2007, a consulta feita à sociedade ocorreu na dimensão das grandes prioridades nacionais, resultando na dificuldade governamental em demonstrar de que forma foram aproveitadas, na feitura do PPA, as contribuições oriundas dos fóruns participativos nos programas e políticas contidos no Plano. A dificuldade da sociedade enxergar sua contribuição em um nível mais concreto da política gerou enorme frustração da sociedade e um sentimento de não identidade com o novo Plano. 
De acordo com a Constituição Federal o PPA deve ser entregue pelo Executivo ao Congresso Nacional até 30 de agosto do primeiro ano de mandato de um novo Presidente da República. A elaboração de um PPA na esfera do governo federal é um processo complexo, que envolve uma ampla gama de atores políticos da sociedade, dos estados e municípios e dos outros poderes da república. Todas essas áreas e atores devem se manifestar na etapa da construção do Plano e explicitar suas prioridades de acordo com as orientaçóes emanadas pelo Ministério do Planejamento. Além disso, há a necessidade da integração entre o Plano e o Orçamento, isto é, entre planejamento e a alocação de recursos. No PPA 2004-2007 essa integração se dava na dimensão do programa, pois era este elemento que aparecia no Orçamento Geral da União (OGU) com recursos alocados e, consequentemente, com metas físicas e financeiras anuais nos sistemas orçamentários e de planejamento.

Em síntese, a elaboração de um PPA, que ocorre de quatro em quatro anos, é um processo que demanda método, organização e tempo para ser realizado, e por determinação constitucional é inflexível nos prazos e nas etapas que precisam ser realizadas para sua consecução. Essas características relacionadas às regras institucionais do processo de elaboração do PPA representaram sérios obstáculos ao sucesso do processo de participação instalado em 2003. Por sua vez, as consultas á sociedade foram realizadas no período entre maio e julho de 2003, e o PPA, por força de Lei, deveria estar concluído para ser entregue até final de agosto. Sendo assim, houve um descompasso na realização das etapas previstas. Enquanto parte do Governo realizava a consulta à sociedade nos fóruns estaduais, o Ministério do Planejamento, órgão responsável pela elaboração do Plano, levava adiante a realização das demais etapas, junto aos órgáos e ministérios setoriais (elaboração de políticas, programas e açóes). Tal descompasso resultou no aproveitamento insuficiente das sugestóes da sociedade para pautar a elaboraçáo dos programas e açóes, esses sim revestidos de maior concretude na vida da população.

Por fim, o último problema identificado no processo participativo do PPA 2004-2007 referiu-se à dificuldade de dar continuidade à participação social nas demais etapas do ciclo de políticas públicas (planejamento, execução, e controle).

\section{A AuSÊNCIA DE PARTICIPAÇão SOCIAL No PPA 2008-2011}

Para a elaboração do PPA 2008-2011, uma equipe que reunia dirigentes da SG-PR e do Ministério do Planejamento construiu uma proposta de participação que levava em conta o aproveitamento das contribuiçóes da 
sociedade manifestadas nas conferências nacionais realizadas no período. Tratou-se, todavia, de uma proposta que ficou restrita ao apoio da SG-PR e de reduzida parcela da equipe do Ministério do Planejamento e que não conseguiu ultrapassar os muros da tecnocracia instalada na Casa Civil-PR e na alta gerência do Ministério do Planejamento. Desta forma, a proposta de participação social no PPA 2008-2011 não saiu do papel. Por outro lado, não se registra no período em questão mobilizaçôes e articulaçóes importantes da parte da sociedade civil na direção de um processo participativo naquele PPA.

A proposta de participação no PPA 2008-2011, que não chegou a sair do papel, envolvia fortemente os conselhos setoriais de políticas públicas e o aproveitamento das inúmeras deliberaçóes encaminhadas pela sociedade ao governo, no processo da realização das conferências nacionais de políticas públicas. Entretanto, essa proposta enfrentou fortes resistências da área econômica (ministérios da Fazenda e do Planejamento) e da área política (Casa Civil-PR). Por traz da opção governamental de não realizar qualquer processo participativo no PPA 2008-2011 estava a prioridade dada pelo presidente Lula e pelos ministérios da área econômica e da Casa Civil$\mathrm{PR}$ à elaboraçáo e à viabilização do Plano de Aceleraçáo do Crescimento (PAC), que englobava um conjunto de políticas econômicas e sociais planejadas para os quatro anos seguintes, sendo uma de suas prioridades o investimento em infraestrutura, em áreas como saneamento, habitação, transporte, energia e recursos hídricos, entre outros.

A prioridade concedida ao PAC pelo governo federal acabou, até mesmo, por atropelar o processo constitucional de elaboração do PPA 2008-2011, o qual foi elaborado apenas para efeito de cumprimento legal, já que toda a atenção dos órgãos e da cúpula do Executivo estava direcionada ao PAC. Além disso, nesse Plano constavam várias obras de infraestrutura - transposição do Rio São Francisco (região Nordeste do Brasil), Usina de Jirau e Belo Monte ( regióes movimentos da sociedade civil, como o Movimento de Atingidos por Barragens (MAB) e os movimentos sociais do semi árido nordestino. Esses movimentos compartilham de outro projeto de desenvolvimento que defende a construção de pequenas centrais hidroelétricas e a revitalização das margens do Rio Sáo Francisco e não a sua transposição.

Com efeito, o não debate destas questóes com a sociedade camuflava o temor governamental da maior participação da sociedade trazer problemas para a condução do PAC, que o governa priorizava naquele momento e que contava com a participação de vultosos investimentos e interesses privados 
e econômicos. Esse temor se constituía em mais um motivo para a não instituição de processo participativo no PPA 2008-2011. Durante o ano de 2007, quando estava sendo elaborado o PPA 2008-2011, o governo federal lançou o PAC-Infraestrutura (final de janeiro de 2007) e o PAC-Criança (outubro de 2007). Este último se constituiu num pacote de medidas e programas para enfrentar a violência contra crianças e adolescentes.

No final de 2010, quando o governo de Lula da Silva chegava ao fim, o Ministro Luís Dulci foi indagado sobre em que medida a discussáo e a definição do orçamento nacional poderiam ser democratizadas no âmbito nacional e quais, em sua opinião, seriam as diferenças entre a experiência nacional de participação no PPA e a "experiência consagrada" do orçamento participativo municipal. Em resposta a esta indagação o então Chefe da SG-PR apresentou a seguinte reflexão:

[...] penso que o chamado ciclo orçamentário isto é, o Plano Plurianual, a Lei de Diretrizes Orçamentárias e o Orçamento propriamente dito, também pode ser, de alguma maneira, objeto de interlocução específica com a sociedade civil. Já acumulamos uma boa experiência nesse sentido. Mas é preciso encontrar a forma adequada para fazê-lo. Náo acredito, sinceramente, na transposição mecânica do orçamento participativo municipal para o âmbito federal. O Orçamento Participativo local tem um caráter de participação direta, inclusive do cidadão individual, que é impossível manter num universo potencial de quase 200 milhôes de pessoas. Além disso, a escala territorial é outra, os condicionamentos institucionais são completamente diferentes, o próprio Congresso Nacional tem atribuiçôes na matéria que as Câmaras de Vereadores não possuem. Mas nessa área também é importante a participação social. Será preciso bolar um formato ao mesmo tempo legítimo e eficaz. Talvez ela possa ser feita por meio de entidades populares representativas. A Secretaria-Geral da Presidência chegou a propor aos movimentos sociais um conselho de acompanhamento do ciclo orçamentário. No próximo governo, quem vier a coordenar o diálogo com a sociedade civil poderia, quem sabe, retomar essa (Leblon 2010). 


\section{A CRIAÇÁO E AMPLIAÇÃO DE NOVOS ESPAÇOS PARTICIPATIVOS NO CAMPO DAS POLÍTICASS PÚBLICAS - CONSELHOS E CONFERÊNCIAS NACIONAIS}

\section{OS CONSELHOS NACIONAIS NO PERÍODO 2003-2010}

A abertura de novos conselhos nacionais de políticas públicas esteve na pauta governamental no período 2003-2010, sobretudo nos anos de 2003 e 2006, constituindo-se em mais um marco participativo que vai ao encontro dos princípios do Projeto Democrático Participativo. É importante observar que houve no período analisado um movimento de colocar em prática outro modelo de gestão de políticas públicas com participação social a partir do aumento quantitativo desses espaços no âmbito da burocracia do governo federal.

Sem se referir ao governo do então presidente Lula, Raichellis (2006) chamou atenção para o significado da ampliação do número de conselhos no Brasil:

A implantação de inúmeros conselhos em diferentes setores revela que está em funcionamento certo "modelo" de participação da sociedade na gestão pública, forjado na dinâmica das lutas sociais das últimas décadas, que busca redefinir os laços entre espaço institucional e práticas societárias, não como polaridades que se excluem, mas como processos conflituosos que se antagonizam e se complementam, pondo em relevo a luta pela inscrição de conquistas sociais na institucionalidade democrática (Raichellis 2006: 12).

Até 2010 existia um total de 35 conselhos nacionais de políticas públicas que contavam na sua composiçáo com representantes da sociedade civil, sendo que 16 (quase a metade) foram criados no período de 2003 a 2010. Chama-se atenção para o fato que a maioria dos conselhos nacionais no período foi criada durante o primeiro mandato do presidente Lula da Silva. Apenas dois conselhos nacionais (Conselho Participativo do Mercosul e o Conselho Nacional de Segurança Pública) foram criados no segundo mandato, em 2008 e 2009 , respectivamente.

Houve, portanto, avanço quantitativo desses espaços públicos na burocracia publica federal no período 2003-2010. Do ponto de vista qualitativo, este artigo não traz informaçóes para uma avaliação definitiva. No entanto, quando se considera que a qualidade de um arranjo participativo pode ser influenciada pela força de suas decisóes e pela forma como escolhe seus representantes, sendo que a eleição é a melhor forma de escolha em um fórum democrático, conclui-se que os novos espaços 
constituídos no período não reúnem todos os requisitos de qualidade.

Do total de 19 conselhos nacionais de políticas públicas, criados antes de 2003, em apenas três (15\%), os representantes da sociedade civil não são eleitos de forma democrática e são indicados por autoridades governamentais, como ministros e Presidente da República: 1) Conselho Nacional de Ciência e Tecnologia (Ministério da Ciência, Tecnologia e Inovação); 2) Conselho Nacional de Política Criminal e Penitenciária (Ministério da Justiça); 3) Conselho Nacional do Esporte (Ministério do Esporte). Nos demais conselhos, os representantes da sociedade civil, ou são indicados pelas próprias entidades e depois designados por atores governamentais, ou são escolhidos via processo eleitoral.

No conjunto de 16 conselhos nacionais criados no período de 2003 a 2010, em mais de 60\% destes (10 conselhos nacionais) os representantes da sociedade civil não são eleitos e são indicados por ministros de Estado ou pelo Presidente da República, evidenciando fragrante discordância com os princípios democráticos que deveriam pautar a constituição desses arranjos participativos. Esses 10 conselhos são os seguintes: 1) Conselho da Transparência Pública e Combate à Corrupção (CGU); 2) Conselho de Desenvolvimento Econômico e Social (Secretaria de Planejamento e Investimento Estratégico); 3) Conselho Nacional de Economia Solidária (Ministério de Trabalho e Emprego); 4) Conselho Nacional de Juventude (Secretaria Nacional de Juventude); 5) Conselho Nacional de Política Cultural (Ministério da Cultura); 6) Conselho Nacional de Políticas sobre Drogas (Gabinete de Segurança Institucional da Presidência da República); 7) Comissão Nacional de Desenvolvimento Sustentável dos Povos e Comunidades Tradicionais (Ministério do Desenvolvimento Social e Combate à Fome); 8) Conselho Brasileiro do Mercosul Social e Participativo (SG-PR e Ministério das Relaçóes Exteriores); 9) Conselho Nacional de Defesa Civil; 10) Conselho Nacional de Promoção da Igualdade Racial (Secretaria Especial de Políticas de Promoção da Igualdade Racial), o qual tem parte de seus representantes da sociedade civil indicados pelo (a) Presidente da República.

No que se refere à natureza das decisóes dos conselhos Nacionais, nota-se que entre os 19 conselhos criados antes de 2003, apenas três são consultivos, os demais têm natureza deliberativa No conjunto dos conselhos nacionais criados após 2003, essa relação se inverte, pois dos 16 conselhos criados nesse período, apenas seis são deliberativos e a maioria (10 conselhos) tem natureza consultiva. 


\section{As ConferênCias Nacionais Realizadas no PERíodo 2003-2010}

Para dinamizar o diálogo com a sociedade na administração pública no período 2003-2010, o governo federal colocou em prática uma estratégia de apoio à realização de conferências nacionais e de criaçáo de novos conselhos nacionais de direitos e de políticas públicas. As conferências nacionais são espaços amplos de participação, onde representantes do poder público e da sociedade discutem e apresentam propostas para o fortalecimento e adequação de políticas públicas específicas:

[...] são espaços mais amplos que os conselhos envolvendo outros sujeitos políticos que não estejam necessariamente nos conselhos, por isso, têm também caráter de mobilização social. Governo e sociedade civil, de forma paritária, por meio de suas representaçóes deliberam de forma pública e transparente. Estáo inseridas no que chamamos de democracia participativa e do sistema descentralizado e participativo, construído a partir da Constituição de 1988 e que permite a construção de espaços de negociação, a construçáo de consensos e dissensos, compartilhamento de poder e a corresponsabilidade entre o Estado e a sociedade civil. Sáo precedidas de conferências municipais/regionais e estaduais e são organizadas pelos respectivos conselhos(Moroni 2006).

Em torno da participação social nas conferências nacionais, assistiu-se neste período a uma situação inédita, pois nunca os segmentos organizados da sociedade haviam demonstrado tanto dinamismo, nas mais diferentes áreas de políticas públicas. Entre 2003 e 2010 foram realizadas 73 conferências nacionais, mobilizando, de acordo com dados da SG-PR, cerca de 5.000.000 de pessoas, quando considerados os desdobramentos das conferências estaduais e municipais. Do total de conferências nacionais realizadas no período em referência, 28 conferências foram realizadas pela primeira vez no governo do presidente Lula. Os novos temas tratados pelas conferências têm um significado muito importante para a luta de inúmeros segmentos e organizaçóes da sociedade civil, na medida em que significa a inserção do tema na agenda de políticas públicas do Governo Federal, mesmo que nunca alcance o conjunto das questóes tratadas na agenda prioritária.

Temas como cidades, pesca, cultura, desenvolvimento rural, comunicação, economia solidária, gays, lésbicas, bissexuais, travestis e transexuais, igualdade racial, juventude, políticas para mulheres, saúde ambiental, educação e saúde indígena, segurança pública, pessoa idosa, pessoa com deficiência e povos indígenas foi, pela primeira vez, debatidos em conferências nacionais. Dessas emanam deliberaçóes da sociedade 
para a produção de políticas públicas, que são acolhidas pelos conselhos nacionais, os quais são responsáveis pelo encaminhamento para dentro da burocracia pública federal, visando sua posterior concretização em políticas, programas ou outros tipos de açóes governamentais. Uma análise da participação social, que considera dois indicadores - número de conferências realizadas e novos temas tratados na agenda governamental de políticas públicas - coloca o período 2003-2010 como aquele que trouxe mais avanços quantitativos nesta área.

No entanto, a análise de aspectos mais qualitativos das conferências nacionais, como a capacidade desses arranjos participativos fazerem valer suas decisóes e de transformarem suas deliberações em políticas ou medidas governamentais concretas, evidencia que, sob essa ótica, o período estudado não logrou muitos avanços. Um Levantamento realizado em 2007 pelo Instituto de Pesquisa Econômica Aplicada (IPEA), em parceria com a SG-PR (Rocha 2009), sobre o conjunto de conferências nacionais realizadas no primeiro mandato do governo do presidente Lula da Silva identificou vários problemas que atuam reduzindo a efetividade das conferências nacionais em relação à capacidade das mesmas em fazerem valer suas decisóes.

No tocante à natureza de suas decisóes, o referido trabalho do IPEA mostrou que a natureza consultiva-propositiva das conferências é a predominante: 23 conferências definiram suas decisóes como sendo consultivas e/ou propositivas. Isto é, a partir do debate interno são construídas propostas, que não têm a força de uma deliberação, são apenas indicativas dos anseios e das reivindicaçóes de seus participantes. Apenas 11 conferências definiram suas decisôes como deliberativas, as quais, por definiçáo, deveriam ser recebidas/encaminhadas pelos governos com a força de lei/decisão a ser homologada e encaminhada. Neste caso, o não encaminhamento e avaliação das deliberaçôes deveriam envolver negociaçôes ou justificativas válidas e convincentes sobre impossibilidade com os autores das deliberaçóes. $\mathrm{Na}$ verdade, a definição da natureza de determinada conferência, na ausência de legislação específica, é geralmente do conselho nacional ou outro órgão público responsável por sua organização. Em geral, a natureza das decisôes de uma conferência, ou ainda seria mais adequado chamar de a força de suas decisóes, está diretamente relacionada ao seu grau de institucionalização do ponto de vista da existência de legislação que respalda (obriga) a sua realização. Assim, as deliberaçóes de conferências de políticas públicas constitucionais como, por exemplo, são os casos das políticas de saúde e da assistência social, nas quais as conferências são vinculadas de forma orgânica à política pública têm mais força na esfera dos órgãos decisórios de âmbito federal, 
mesmo que tal fato não se reflita na garantia da implementação.

Uma das formas de se garantir a continuidade de realização de conferências nacionais é a sua institucionalização, isto é, a existência de instrumentos legais que obrigam a sua realização em determinado período de tempo. Geralmente, quem institui a obrigatoriedade e a periodização de realização das conferências são os conselhos nacionais. Assevera-se que a institucionalização das conferências é um expediente da maior importância no âmbito da esfera pública federal, pois sua previsão autoriza a alocação de recursos no OGU, viabilizando financeiramente a sua realização. Entretanto, do conjunto de 34 conferências pesquisadas, 20 (cerca de $60 \%$ ) não contavam ainda com qualquer instrumento legal que garantisse a sua continuidade, independente das mudanças governamentais.

O conjunto de conferências realizadas no período 2003-2006 produziu um número extenso de deliberaçóes. De acordo com o referido Levantamento, do universo das 34 conferências nacionais pesquisadas, apenas quatro não tiveram deliberaçôes aprovadas 17. As demais 30 conferências analisadas pelo Levantamento conduzido pelo IPEA e a SGPR produziram conjuntamente um total de 8.047 deliberaçóes, ou seja, uma média de aproximadamente 270 deliberaçóes por conferência, relativas aos mais diversos temas de políticas sociais. Do total das deliberaçóes, 45\% (3.624) demandavam encaminhamento de competência exclusiva do ministério responsável pela realização da conferência e 55\% (4.423) requeriam encaminhamento de competência compartilhada. Isto é, as deliberações tratavam de questôes que mantinham interface com outras áreas do Executivo exigindo que a articulação e a atuação da parte do Conselho ou órgão responsável pela realização da conferência com mais de um ministério/órgão da esfera pública federal.

Em função do expressivo número de deliberaçôes e da complexidade dos encaminhamentos, sobretudo, quando esse envolvia atuação compartilhada de diferentes órgãos de âmbito federal, mais da metade dos entrevistados (19 coordenadores nacionais), quando indagada sobre como se dava o processo de encaminhamento no âmbito da esfera pública federal, assinalou o item não sabe. Em duas conferências, os entrevistados disseram que as deliberaçôes não eram encaminhadas; em cinco, informaram que os resultados das conferências eram encaminhados por meio da realização de reunióes interministeriais, onde se processava o encaminhamento; e em quatro, o encaminhamento é realizado por intermédio do conselho nacional, ou seja, os conselhos teriam expedientes e mecanismos próprios para proceder ao encaminhamento dos resultados das conferências aos canais apropriados no âmbito da esfera pública. 
Do processo de encaminhamento dos resultados das conferências nacionais, apreende-se que o que é feito dos resultados das conferências ainda não é de conhecimento amplo. Além disso, pode-se afirmar que os resultados das conferências nacionais não encontram vazão automática para dentro da esfera pública federal. Ou seja, o processamento das deliberaçóes das conferências pelo governo federal ainda padece de um método institucional de gestão, pois o que se identificou é que cada conselho/ministério processa os encaminhamentos da forma que mais lhe aprouve. Sendo que há aqueles que sequer sabem como são (e se são) feitos os encaminhamentos para as deliberações das conferências que realizaram.

Dessa forma, é importante chamar atenção para o fato de não existir procedimento institucional que garantam que as deliberaçóes das conferências tenham força no âmbito das decisóes do Executivo e do Legislativo e incidam no ciclo de elaboração, controle e gestão de políticas públicas. Indagados sobre a existência de dificuldades no âmbito das instituiçôes formais para o encaminhamento (providências para a resolução) das deliberaçôes das conferências, a maioria dos entrevistados admitiu que o conselho e/ou órgão responsável enfrenta, de fato, inúmeras dificuldades nesta esfera, destacando-se:

1. Problemas internos no âmbito do próprio ministério responsável pela organização da conferência, principalmente quanto à dificuldade de negociação visando garantir a prioridade para a implementação das deliberaçóes das conferências.

2. Questôes referentes à complexidade da temática das conferências, sobretudo, aquelas que tratam de temas transversais, cujos encaminhamentos envolvem a articulaçáo com uma multiplicidade de órgãos federais, tais como as deliberaçôes relativas a direitos humanos, esporte, cultura, gênero, raça, criança e adolescente, entre outras.

3. Falta de recursos humanos e infraestrutura nos conselhos nacionais para dotá-los de maior capacidade de pressão e negociação no momento do encaminhamento das deliberaçóes das conferências.

Entre as causas das dificuldades enfrentadas para o processamento adequado das deliberaçóes das conferências nacionais, destacaram-se as seguintes:

1. Inexistência de estratégia de coordenação horizontal entre as diversas conferências nacionais, resultando em dificuldades para a identificação e para o encontro de soluçóes para os inúmeros casos de deliberaçôes recorrentes, sobrepostas e, muitas vezes, antagônicas entre si 
2. Realização de conferências, sobre o mesmo tema ou similares, com intervalo muito curto entre uma e outra, restando aos conselhos e/ ou aos ministérios um prazo reduzido para processar os resultados das mesmas.

3. Ausência de acompanhamento das deliberaçóes encaminhadas, resultando em dificuldades de prestaçáo de contas para a sociedade em relação aos resultados efetivos de sua participaçáo.

4. Ausência de integração entre as decisóes tomadas nos conselhos nacionais, referentes ao encaminhamento das deliberaçóes das conferências, e as tomadas no âmbito do Congresso Nacional. Tal aspecto resulta, muitas vezes, em decisóes do Congresso Nacional que desrespeitam as deliberaçóes da sociedade advindas do processo de conferências nacionais.

\section{CONSIDERAÇÓES FINAIS}

As iniciativas relacionadas à participação social colocadas em prática nos dois mandatos do governo do presidente Lula da Silva são consideradas avanços no âmbito da administração pública federal, notadamente com maiores dificuldades de compartilhar suas decisóes com a sociedade, quando comparada às administraçôes públicas locais.

Este artigo analisou as principais inovaçóes introduzidas no período 2003-2010 para a ampliação da participação da sociedade na burocracia das políticas públicas do governo federal: 1) o novo arranjo da estrutura da Presidência da República, com as novas atribuições delegadas à SG-PR; 2) a tentativa de elaboração do PPA participativo; 3) a ampliação do número de conselhos nacionais de políticas públicas; e a realização de maior número de conferências nacionais, com a introdução de novos temas e novos atores na agenda nacional de políticas públicas.

A análise empreendida neste artigo mostrou que, no período 2003-2010: 1) a participação social não ocupou um papel constitutivo da política; 2) não houve compartilhamento das decisóes que envolvem o ciclo de elaboração e execução de políticas públicas no âmbito da administração pública federal; 3) não houve a participação social na discussão ou decisões sobre os grandes investimentos de infraestrutura, ou seja, a sociedade civil não era ouvida nas discussões sobre modelo de desenvolvimento; 4) apesar do reconhecimento dos novos atores, não foram dadas as condiçóes administrativas e financeiras para acelerar a inclusão e a criação de novos direitos. 
Entretanto, o avanço quantitativo da participação social ocorrido no período 2003-2010 contribuiu para o aumento do controle social e para deixar o Estado mais permeável ao interesse público, dialogando com a matriz do projeto democrático participativo. Mas, os avanços mostraramse insuficientes para romper com os traços do projeto político neoliberal que não coloca a participação da sociedade como elemento fundador da política e da definição da direção do desenvolvimento do país.

A análise apresentada neste artigo evidenciou que o aumento da participação social no âmbito federal mostrou contradiçóes e limites, que precisam ser explicitados e enfrentados. O Tabela 2, abaixo, apresenta uma síntese das principais contradiçóes encontradas nos avanços da participação social registrados entre os anos 2003-2010 no governo federal, comprometendo a qualidade do qualificativo público dos espaços de participação.

Citando Dagnino (2006), a garantia de espaços efetivamente públicos é assegurada por meio da efetiva pluralidadee diversidade de seus participantes; pela equivalência de seus recursos de informação, conhecimento e poder. Além desses indicadores, acrescenta-se ainda a capacidade dos espaços públicos de participação fazerem valer suas decisôes, influenciando, de fato as decisões governamentais para o fomento de políticas públicas mais justas e promotoras da igualdade social e econômica. Com efeito, as inovaçóes participativas introduzidas no governo federal carecem de qualificativos fundamentais para serem espaços efetivamente públicos. A maioria limita a participação da sociedade nas questóes periféricas da agenda governamental, impedindo a participação nas questôes de grande impacto na vida da população, como são as questôes que permeiam o debate social e econômico. Os novos espaços criados também padecem da ausência de ferramentas adequadas para, de fato, conseguirem ser mais efetivos nas suas propostas e deliberaçôes.

As dificuldades para concretizarem suas decisóes em propostas concretas de políticas públicas relacionam-se, no caso dos conselhos nacionais, com o fato de muitos desses arranjos serem apenas consultivos com fraco poder para fazerem valer suas decisóes. $\mathrm{O}$ mesmo se observou no caso das conferências nacionais, de forma similar aos dos conselhos, mas agregando o aspecto de as conferências não contarem com nenhum mecanismo procedimental que obrigue que sejam cumpridas suas determinaçóes. $\mathrm{Na}$ maioria das conferências realizadas não há acompanhamento e monitoramento sobre o que é feito das deliberaçóes das conferências no âmbito da burocracia federal, grande parte sequer é contemplada no Plano Plurianual. Por último, a ausência de eleição como critério fundamental para escolha dos representantes da sociedade nos conselhos nacionais, 
comprometem, ainda, a pluralidade e a diversidade da participação nos novos espaços.

\section{Tabela 2: Participaçáo Social: Avanços e Contradiçóes no período 2003-2010}

Avanços
Novo papel desempenhado pela SG-PR
Participação no PPA 2004-2007
$\begin{aligned} & \text { Ampliação do número de conselhos } \\ & \text { nacionais }\end{aligned}$

nacionais

\section{Principais contradiçóes}

O processo de diálogo com a sociedade limita a participação social a questóes periféricas, excluindo a participação das discussóes das estratégias de desenvolvimento. Por exemplo: PAC, modelo energético, proibição de acesso à informação aos sistemas (Siafi e Sistema de Informaçôes Gerenciais para o Planejamento, Sigplan).

Participação incompleta. Ausência de participação ao longo do ciclo orçamentário. A participação social foi apenas na dimensão da formulação dos desafios estratégicos do Plano

Fraqueza das decisóes (muitos conselhos criados são apenas consultivos e não deliberativos)

Escolha dos representantes não é feita por meio de eleição.

Realização de maior número de $\begin{aligned} & \text { Fraqueza das decisóes } \\ & \text { Ausência de procedimentos formais para o }\end{aligned}$ conferências nacionais

Fonte: Elaboraçâo própria.

Os desafios enfrentados pelos arranjos participativos existentes na esfera pública federal remetem à discussão em torno da esfera pública habermasiana. Os conselhos e as conferências nacionais inscrevem-se nos debates da teoria democrática contemporânea, no percurso que foi iniciado por Habermas (1997), que definiu a esfera pública política como estrutura comunicacional enraizada no mundo da vida por intermédio da sociedade civil. Na esfera pública habermasiana, os problemas são percebidos, identificados, tematizados e dramatizados; os fluxos comunicacionais são filtrados e condensados em opinióes públicas. Habermas entende o mundo da vida como uma arena de integração social, o domínio das interaçooses cotidianas, que se constituem em um reservatório de tradiçóes culturais. 
No entanto, o conceito de esfera pública formulado por Habermas não contempla a participação da sociedade civil nos níveis decisórios sistêmicos, reservando aos atores civis a dimensão informal que pode (ou não) influenciar os domínios institucionais.

Cohen e Arato (1992), dois dos principais críticos da esfera pública de Habermas propóem alargar o papel reservado aos atores sociais, possibilitando uma atuação mais constitutiva e não apenas defensiva. Esses autores sustentam que a saída consistiria em introduzir espaços públicos no Estado e nas instituições econômicas, estabelecendo uma continuidade com uma rede de comunicação composta por movimentos sociais, associaçôes e esferas públicas.

A principal crítica de Cohen à esfera pública de Habermas reside na reduzida influência dos fluxos comunicativos sobre as decisóes tomadas pelo poder político. Cohen apresenta uma tese que pressupóe a existência de mecanismos institucionais que regulam o funcionamento da esfera pública, tornando obrigatório o reconhecimento dos resultados alcançados no processo de deliberação e, com isso, aumentar a influencia sobre os poderes oficialmente estabelecidos (Ribeiro 2007: 41). Na mesma direção, Avritzer (2002) critica a visão habermasiana de esfera pública, sobretudo, pelo fato dessa náo considerar a capacidade dos atores civis incidirem efetivamente nas decisóes do poder político. Assim, este autor assevera que os espaços de mediação entre a sociedade e o Estado sáo, por excelência, o lócus da democracia deliberativa, incluindo a possibilidade de soberania popular procedimentalizada entre os espaços participativos e representativos.

Entretanto, em relação aos postulados de Avritzer é importante ponderar que, no mundo empírico, os conselhos não reúnem todas essas prerrogativas. Enfrentam imensas dificuldades para efetivarem suas decisôes. Ou seja, a maioria dos arranjos participativos nacionais - conselhos e conferências - não conta com ferramentas que obriguem o reconhecimento de suas deliberaçóes, o que resulta em reduzida influência sobre o Executivo e o Congresso Nacional.

Frazer (1993), também criticando a esfera pública habermasiana defende que a força da opinião pública é potencializada quando um espaço público que a representa tem o poder de traduzir suas opinióes em decisóes autorizativas. Esta autora, ao refutar a premissa de Habermas de que o funcionamento de uma esfera pública democrática requer uma clara separação entre a sociedade civil e o Estado, pondera que essa visão é responsável pela criação de espaços públicos débeis, afirmando que: 
[...] Como consequência, se promove o que eu chamarei de os espaços públicos débeis, cuja prática de deliberaçáo consiste exclusivamente na formação de opiniōes, e não inclui a tomada de decisôes. Além disso, a concepçáo burguesa de esfera pública insinua que uma ampliação para além da autoridade discursiva do espaço público, que inclui os processos de tomada de decisóes, ameaçaria a autonomia da opinião pública, já que, desta forma, o público se transformaria no Estado e com isso perderia a possibilidade de exercer um discurso crítico à atuação do mesmo (Frazer 1993: 24. Tradução livre da autora).

As críticas feitas à formulação habermasiana de esfera pública, resguardando suas especificidades, trazem subjacente a necessidade de maior empoderamento dos arranjos participativos, concedendo-lhes o poder da deliberaçáo e incluindo mecanismos e procedimentos que concedam maior força às decisôes da sociedade.

São essas as contradiçóes que atuaram comprometendo o alcance dos avanços dos espaços participativos criados no período 2003-2010, dificultando, por exemplo, o encaminhamento das decisóes das conferências nacionais no ciclo de elaboração e planejamento de políticas públicas, única via de implementação de políticas públicas governamentais.

O rico processo de participação social, que teve lugar no período 20032010 remete à reflexão sobre as dificuldades que precisam ser enfrentadas para concretizar o potencial dos arranjos participativos em espaços públicos fortes, que mantém interconectividade com o processo decisório de políticas públicas. A disputa de projetos políticos existente na esfera pública federal é o elemento de fundo, de onde emergem as principais dificuldades e os desafios que precisam ser enfrentados para que a participação social se torne elemento constitutivo da política. 


\section{REFERÊNCIAS}

Avritzer, L. (2000). Teoria Democrática e Deliberação Pública. Lua Nova, 49, 25-46

. (2002). Democracy and the Public Space in Latin America. Oxford: Princeton University Press.

. (2008). Instituiçôes Participativas e desenho Institucional: Algumas Consideraçôes sobre a Variação da Participaçáo no Brasil Democrático. Revista Opinião Pública, 14 (1), 43-64.

Bohman, J. (1996). Public Deliberation: Pluralism, Complexity, and Democracy. Londres: The MIT Press.

Cohen, J. e Arato, A. (1992). Civil Society and Political Theory. Cambridge: The MIT Press.

Cohen, J. 1998. Reflections on Habermas on Democracy. Artigo apresentado no European University Institute, Mimeo.

Coutinho, M. (2006). Movimentos e Mudança Política Na América do Sul Contemporânea. Revista de Sociologia e Política, 27, 107-123.

Dagnino, E. (2002). Sociedade Civil, Espaços Públicos e a Construção Democrática no Brasil: Limites e Possibilidades. Em Dagnino, E. (Ed.), Sociedade Civil e Espaços Públicos no Brasil. São Paulo: Paz e Terra.

-. (2004). ¿Sociedade civil, Participação e Cidadania: De Que Estamos Falando? Em Mato, D. (Ed.), Políticas de Ciudadanía y Sociedad Civil en Tiempos de Globalización. Caracas: Universidad Central de Venezuela.

Dagnino, E., Olvera, J. A. e Panfichi, A. (2006). Para uma Outra Leitura da Disputa pela Construção Democrática na América Latina. Em Dagnino, E., Olvera, J. A. e Panfichi, A. (Eds.), A Disputa pela Construção Democrática na América Latina. Rio de Janeiro: Paz e Terra.

Dahl, R. (1997). Poliarquia. São Paulo: Edusp.

Frazer, N. (1993). Rethinking the Public Sphere: A Contribuition to the Critique of Actually Existing Democracy. Em Robbins, B. (Ed.), The Planton Sphere. Minnesotta: University of Minnesotta Press.

Fung, A. e Wright, E. (2003). Countervailing Power in Empowered Participatory Governance. Em Fung, A. e Wright, E. (Eds.), Deepening 
Democracy: Institutional Innovations in Empowered Participatory Governance. Londres: Verso.

Habermas, J. (1995). Três Modelos Normativos de Democracia. Lua Nova, $36,39-53$.

(1997). Direito e Democracia: Entre Factilidade e Validade. Rio de Janeiro: Tempo Brasileiro.

Laisner, R. (2008). Visôes da Democracia: O Debate entre Tradiçóes e o Caminho para um Novo Modelo. Revista de Estudos e Pesquisas sobre as Américas, 2, 12-27.

(2009). A Participação em Questão: Ponto ou Contraponto da Representação na Teoria Democrática. Estudos de Sociologia, 14 (26), $17-35$.

Leblon, S. (2010), A Elite Chama de Populismo a Democratização das Decisóes. Disponível na http://www.cartamaior.com.br/?/Editorial/A-elite-chama-de-populismo-a-democratizacao-das-decisoes/23512 [05-03-2014].

Lubambo, C. e Coelho, D. (2005). Governos e Sociedade Civil Aprendem: O que Revela a Experiência Recente de Participação em Pernambuco. Em Lubambo, C., Coêlho, D., e Melo, M. (Eds.), Desenho Institucional e Participaçāo Política: Experiências do Brasil Contemporâneo. Petrópolis: Vozes.

Lubambo, C. W., Coelho, D. B. e Melo, M. A. (2006). Diseño Institucional y Participación Politica: Experiencias en el Brasil Contemporáneo. Buenos Aires: CLACSO.

Lüchmann, L. (2002). Possibilidades e Limites da Democracia Deliberativa: A Experiência do Orçamento Participativo de Porto Alegre. Tese (Doutorado), Universidade Estadual de Campinas, Campinas, Brasil.

Moroni, A. J. (2006) O Direito à Participação no Governo Lula. 2006. Artigo apresentado no 32nd International Conference on Social Welfare, 16 a 20 de julho, Brasilia, Brasil.

Pateman, C. (1992). Participação e Teoria Democrática. Rio de Janeiro: Paz e Terra.

Raichellis, R. (2006). Democratizar a Gestão das Políticas Sociais - Um Desafio a Ser Enfrentado pela Sociedade Civil. Em Mota, A. et al. 
(Eds.), Serviço Social e Saúde: Formação e Trabalho Profissional. São Paulo: OPS.

Ribeiro, A. (2008). O Dilema em torno da Esfera Pública: A Centralidade do Conceito Dentro da Teoria Deliberativa da Democracia e suas Reformulações a Partir da Proposta Habermasiana. Revista Habitus, 5 (1), 37-46.

Rocha, E. (2009). A Conferências Nacionais de Políticas Públicas: Reflexóes sobre Avanços e Desafios no Periodo 2003-2006. Rio de Janeiro: IPEA. . (2013). Projetos Políticos e Arranjos Participativos Nacionais no Período 2003-2010: Os Sgnificados e os Desdobramentos no CNS e no Conanda. Tese (Doutoramento) Universidade Estadual de Campinas, Campinas, Brasil.

Schumpeter, J. (1974). A Instabilidade do Capitalismo. Em Carneiro, R (Ed.), Os Clássicos da Economia. São Paulo: Ática.

Tatagiba, L. (2002). Os Conselhos Gestores e a Democratização das Políticas Públicas no Brasil. Em Dagnino, E. (Ed.), Sociedade Civil e Espaços Públicos no Brasil. São Paulo: Paz e Terra.

Recibido: 05-03-2014

Aceptación de la versión final: 24-06-2014 